RESEARCH ARTICLE

\title{
BULLYING VIOLENCE AGAINST UNDERAGE CHILDREN IN CRIMINAL LAW PERSPECTIVE ACCORDING TO LAW NO. 23 OF 2002
}

\author{
Arief Ramadhani $^{1 \bowtie}$, Ali Masyhar ${ }^{2}$ \\ ${ }^{1}$ Polresta Surakarta, Indonesia \\ ${ }^{2}$ Faculty of Law, Universitas Negeri Semarang, Indonesia \\ $\triangle$ arieframadhanihd48@gmail.com
}

\section{CITED AS}

Ramadhani, A., \& Masyhar, A. (2020). Bullying Violence Against Underage Children in Criminal Law Perspective According to Law No. 23 of 2002. Journal of Law and Legal Reform, 1(4), 641-648. https://doi.org/10.15294/jllr.vli4.38581

\section{ABSTRACT}

The case of bullying is now rampant among the public, not only in the community but this case occurs in the world of education. Many underage children are victims of bullying. Various methods were used to minimize the incidence of bullying in schools, and at home including one of the National Commission for Child Protection urged the school to better protect and pay attention to their students. Speaking of child violence, it was found that children could be the subject / actor and object of violence. Children as perpetrators of violence / subject, usually because he has experience as an object of violence itself. Children behave like that as part of imitation or expression of their experiences, whether conscious or not. Violence in children depends on parenting and the pattern of treatment of parents towards children. Child care patterns also greatly affect the child's personality. This parenting style determines how children interact with their parents. Bullying actors will assume that the best way to solve the problem is by means of violence or the perpetrator thinks that by intimidating others it will fulfill his wishes. This will encourage the nature of thuggery that will carry over into adulthood and cause discomfort in the community.

Keywords: Bullying; Underage Children; Violence; Crimes 


\section{TABLE OF CONTENTS}

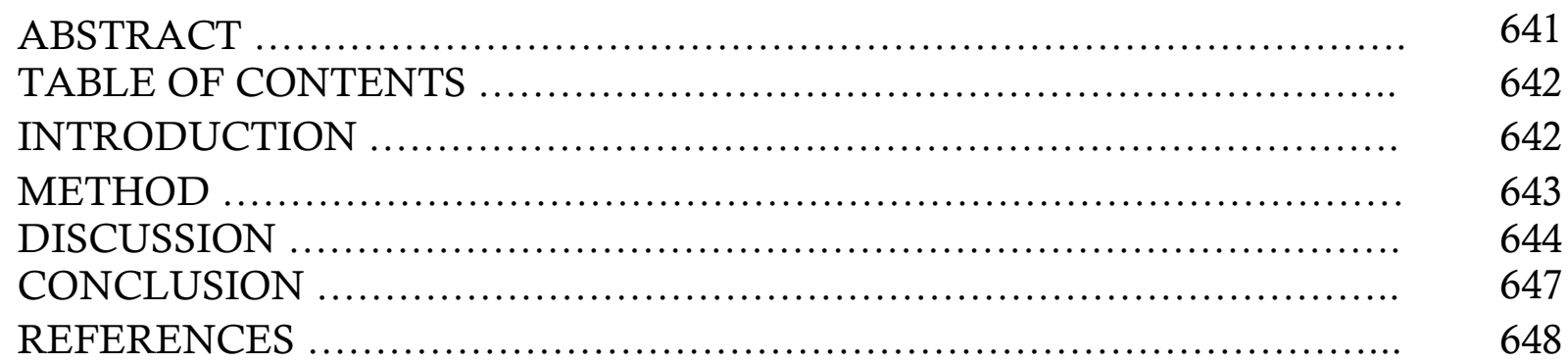

\section{INTRODUCTION}

Bullying cases are now rife among the people, not only in the community but this case is happening in the world of education. Many underage children are victims of bullying. Various methods are used to minimize the incidence of bullying at school, and at home including one of the National Commission for Child Protection urges the school to better protect and pay attention to their students.

Bullying can have the potential to be an arbitrary person. If these things continue to be left in the fabric of their lives, the perpetrators will grow into criminals or authority figures who have no empathy for others. The perpetrators of bullying will assume that the best way to resolve the problem is by means of violence or the perpetrators assume that intimidating others will fulfill their wishes. This will encourage the nature of thuggery that will carry over into adulthood and cause discomfort in society.

Bullying is a form of aggression in which there is an unbalanced force between the perpetrator and the victim. Perpetrators always have more power than victims. Bullying can take the form of physical, verbal and psychological actions. Bullying can occur directly (face to face) or indirectly (hiding behind other people). Examples of acts of direct bullying are hitting and cursing people. According to Craig (2000) examples of acts of indirect bullying are exclusion and gossip.

According to Amini (2008) the impact that occurs due to bullying behavior is being alone, crying, asking to change schools, reducing children's concentration, learning achievement decreases, not wanting to socialize, children become timid, anxious, lying, depressed, being quiet, not excited, aloof, sensitive, anxious, easily 
offended, to cause mental disorders. Bullying does not only affect victims, but also the perpetrators. Intimidating actions are also bad for victims, witnesses, even for the perpetrators themselves,

Speaking of child abuse, it was found that children can be the subject / perpetrator and object of violence. Children as perpetrators of violence / subjects, usually because he has experience as an object of violence itself. Children behave like that as part of an imitation or expression of their experiences, whether they are aware of it or not. Violence in children depends on parenting and parental treatment of children. Parenting children also greatly affect the child's personality. This parenting determines how children interact with their parents.

According to Law No. 23 of 2002 concerning child protection, child protection aims to ensure the fulfillment of children's rights so that they can live, grow, develop, and participate optimally in accordance with human dignity and dignity, and get protection from violence and discrimination, for the realization of Indonesian children of good quality, noble, and prosperous. And also every child has the right to be able to live, grow, develop, and participate appropriately in accordance with human dignity and dignity, and get protection from violence and discrimination.

\section{METHOD}

The approach used in this research is a qualitative approach. According to Sugiyono, (2015) Qualitative method is a research method used to examine the natural object's condition, where the researcher is a key instrument. Meanwhile, according to Bogdan and Taylor (2013) Qualitative methods as a research procedure that produces descriptive data in the form of written or spoken words from people and observable behavior.

Qualitative research produces analytical procedures that do not use statistical analysis procedures. Qualitative research itself is based on efforts to build views that are examined in detail, formed with words and described holistically. This definition questions what is examined is an effort to understand the attitudes of views, feelings, and behavior both individuals and groups of people. 


\section{DISCUSSION}

Bullying is an act that is prohibited and is not allowed in any religion. Bullying includes acts of oppression, harassment, or intimidation (English: bullying) is the use of violence, threats, or coercion to abuse or intimidate others. This behavior can become a habit and involve an imbalance in social or physical power.

According to research conducted by Heirman (2012) on subjective norms supports the assumption that adolescents care about the opinions of significant others, with adolescents feeling negative social pressure against bullying, then as adolescents can show a lower intention to do that. Not only understanding bullying but also subjective norms are needed. According to Azwar, (2016) a subjective norm is a person's belief in what other individuals or groups want someone to do. Or rather, subjective norms are one's perceptions of social pressure to do or not do behavior.

Someone's behavior depends on intention, then intention to behave depends on attitude and subjective norms.

According to Amalia (2010) subjective norms are not very influential because internal motivation is more dominant than external motivation. Attitudes toward behavior are influenced by the belief that the behavior will bring to the desired results, beliefs about what is normative.

One belief in behavior and evaluation will determine a person's behavior. For example the case of oppression experienced by Audrey.

In detik.com, the allegations of violence experienced by A started from bickering due to mutual mocking between A and high school students at social media. One student with the initials Ec alias NNA (17) admitted that the fight started from him with A because of his frustration with the victim who often bullied himself at social media. 'A' and the high school students also met on the banks of the Kapuas River, on Friday (29/3) to resolve the quarrel from the social media. When they met, there was a fight. Long story short, after the fight broke out, the victim's mother made a report to Pontianak Police. The police then conducted an investigation, proceeding to the investigation until three suspects were determined, namely Ar, Ec alias NNA, and Ll. "But the fact that there is pulling hair, pushing it to the ground, crunching, and throwing 
slippers. It was done and there was no action to injure the genitals," Pontianak Police Chief Commissioner M Anwar Nasir said, as quoted by Antara

Considering that in the Audrey case, the writer assumes that the case experienced by Audrey is included in the structural tension theory, where structural tension is a condition of tension caused by the reality of community structures such as uncertainty, oppression, conflict, gaps that have the potential for the growth of violence collective. This can be seen from how the perpetrators committed acts of violence against Audrey due to conflict and social inequality. The violence experienced by Audrey is primitive collective violence. Where according to Koesworo (1983), namely acts of violence committed by a group of people who are not political in nature and its scope is limited to local communities.

One of the factors in the presence of acts of violence is that there are several triggers for violence, the following are potential factors that trigger mass violence.

1. Feelings of being threatened and frustrated, support or provocation of others, violent stimulus cues, opportunities, target characteristics, and the victim factor itself.

2. Feelings are threatened to make someone so sensitive to any stimulus from the outside.

3. People who feel threatened are always on standby and on guard.

4. As a result, he perceives the stimulus as biased or excessive.

5. Almost every stimulus is interpreted as a threat so that the reaction is instinctive and aggressive.

6. Likewise when people are in a state of frustration, due to not fulfilling their desires and hopes.

7. In a state of frustration, people act not according to common sense, but emotion so that the reaction is an emotional reaction.

According to article 23 of 2002 concerning the protection of children from cases experienced by Audrey, Audrey herself received acts of abuse that caused great trauma to her mental health.

In Law No. 23 of 2002 concerning Child Protection, it contains criminal offenses that can be imposed on law enforcement. The act of mistreatment experienced by Audrey according to the author enters into Article 80 paragraph (1), (2), and (3) as mentioned below. 


\section{Article 80}

1. Every person who commits cruelty, violence or threats of violence, or child abuse, is sentenced to a maximum imprisonment of 3 (three) years 6 (six) months and / or a maximum fine of Rp. 72,000,000.00 (seventy-two million rupiah).

2. In the case of a child as referred to in paragraph (1) seriously injured, the perpetrator shall be sentenced to a maximum imprisonment of 5 (five) years and / or a maximum fine of Rp 100,000,000.00 (one hundred million rupiah).

In the case of a child as referred to in paragraph (2) dies, the offender is sentenced to a maximum imprisonment of 10 (ten) years and / or a maximum fine of $\mathrm{Rp}$ 200,000,000.00 (two hundred million rupiahs)

Article 44 Health chapter based on Law No. 23 of 2002,

(1) The government is obliged to provide facilities and carry out comprehensive health efforts for children, so that each child receives an optimal level of health from the womb.

(2) Provision of comprehensive health facilities and operations as referred to in paragraph (1) is supported by community participation.

(3) Comprehensive health efforts as referred to in paragraph (1) include promotive, preventive, curative and rehabilitative efforts, both for basic and referral health services.

(4) Comprehensive health efforts as referred to in paragraph (1) shall be held free of charge for disadvantaged families.

(5) Implementation of the provisions referred to in paragraph (1), paragraph (2), paragraph (3), and paragraph (4) shall be adjusted to the provisions of the applicable laws and regulations.

From the article above, it is stated that the government is obliged to provide facilities and carry out comprehensive health efforts for children, so that each child gets an optimal degree of health from the womb. This can be a guideline that acts of violence experienced by Audrey must be one form of government responsibility in the health sector. The government is also demanded to assist victims of violence until the case and the victim's health returns to normal. 
It would be nice minors have strict supervision. Parents at home must play their role by creating good communication with children and equipping children with an adequate understanding of religion and instilling noble moral (ahlakul karimah) which is always carried out in the home environment, because children will always imitate the behavior of parents. Parents must remember that setting an example to children will be far better than giving advice. Parents and the government must accompany children underage so that no more bullying occurs, here are some steps that can be taken to overcome bullying:

a. Tell a trusted adult. Tell parents and teachers who have the authority to follow up on bullying behavior.

b. Frequent discussions with children.

c. Listen to his opinion often. Teach children to always be open with parents, especially parents can teach children to dare to talk if there are things he wants to say so that the environment can still be controlled and supervised by parents.

d. Do not compare children, focus more on praising our children aim to encourage them.

e. Changing yourself so that he is more willing to admit weaknesses without blocking changes for the better.

\section{CONCLUSION}

The conclusion that can be taken is, the triggering factor of bullying is preceded by the spread of public trust, which is something that shows the source of tension, recognizes some of the characteristics of the source, and details certain possible and appropriate responses to tension. Where if hostility is formed for the possibility of violence, then for the realization of such violence, it is only a matter of waiting for the trigger factor and the opportunity for acts of bullying to occur. The advice that the author can give is, the role of parents, and people in the school environment (teachers, principals and school guards) can take preventive measures, this aims to minimize or even eliminate the phenomenon of bullying that occurs in schools. Preventive action can be in the form of socialization about the meaning of bullying and the impact that will be received by victims. specific rules regarding student behavior, and briefing teachers about the importance of understanding bullying. 


\section{REFERENCES}

Amalia, D. (2010). "Hubungan Persepsi Tentang Bullying Dengan Intensi Melakukan Bullying Siswa SMA Negeri 82 Jakarta", Thesis, UIN Syarif Hidayatullah Jakarta

Amini, Y. S. J. (2008). Mengatasi Kekerasan di Sekolah dan Lingkungan Sekitar Anak. Jakarta: PT Grasindo.

Azwar, S. (2016). Sikap Manusia Teori dan Pengukurannya. Yogyakarta: Pustaka Pelajar.

Bogdan, R., \& Taylor, S. (2013). Pengantar Metode Kualitatif. Surabaya: Usaha Nasional.

Craig, W. M., Pepler, D, \& Atlas, R. (2000). Observations of Bullying in the Playgroup and in the Classroom. London: Sage Publication

Fadhil, H. (2019). "Berawal dari Bully di Medsos, Begini Kronologi Kasus Audrey", Online News Detik, retrieved from https://news.detik.com/berita/d4506079/berawal-dari-bully-di-medsos-begini-kronologi-kasus-audrey.

Heirman, W., \& Walrave, M. (2012). Predicting Adolescent Perpetration in Cyberbullying: An Application of The Theory of Planned Behavior. Journal of Psicothema, 24(2), 614-620.

Koeswara, E. (1988). Agresi Manusia. Bandung: PT. Eresco.

Sugiyono, S. (2015). Memahami Penelitian Kualitatif. Bandung: CV. Alfabeta 